Maria Nilsson

Stockholm University

DOI: http://dx.doi.org/10.5617/adno.8310

\title{
Sense of agency among frequently anxious learners of English in Swedish primary school: Mismatching beliefs and experiences
}

\begin{abstract}
Instilling a sense of agency (SoA) in young learners is an important aspect of foreign language instruction, as is the counteracting of emergent foreign language anxiety (FLA). Focusing on learners who frequently experience FLA, this study explores young learners' beliefs and classroom experiences in relation to the teaching and learning of English, in order to highlight the way in which they perceive their own agency, that is, their situated SoA. After initial classroom observations, learners from seven Swedish classrooms, across years $2-5$, were seated in small groups to discuss open questions about target language (TL) use, oral interaction, instructional work mode and the role of the teacher and the learners. The present study is based on discussions among 31 of those learners. Qualitative content analysis of the recorded discussions reveals conflicting beliefs and experiences. These frequently anxious learners stressed the importance of extensive input in English and of learners engaging and speaking the TL. However, they also expressed that oral instructions and prompts, which were sometimes incomprehensible, made them feel frustrated and insecure. Considering the risk of embarrassment, they refrained from asking questions or volunteering to speak. Thus, their accounts of their emotional experiences and actions did not align with their beliefs, which hampered their SoA. The findings illustrate the interrelated nature of beliefs, emotional experiences and agency. Implications for primary language teaching relate to target language use and offering plenty of time for learners to practice their oral skills under conditions that they perceive as safe.
\end{abstract}

Keywords: foreign language anxiety, young learners, learner beliefs, sense of agency, target language use, early language instruction

\section{Upplevd agens hos talängsliga engelskelever i grundskolans tidigare år: Motstridiga föreställningar och erfarenheter}

\footnotetext{
Sammendrag

Att ingjuta en känsla av agens hos unga elever samt att motverka begynnande talängslan är viktiga aspekter av undervisning i främmande språk. Med ett fokus på elever som ofta upplever talängslan utforskar denna studie föreställningar och klassrumserfarenheter i relation till engelskundervisning och språkinlärning på låg- och mellanstadiet, för att därigenom belysa hur eleverna själva uppfattar sin situerade agens. Efter inledande klassrumsobservationer placerades elever från sju svenska klassrum, i
} 
årskurserna 2-5, i smågrupper för att diskutera öppna frågor kring målspråksanvändning, muntlig interaktion, undervisningsformer och lärarens respektive elevernas olika roller. Denna studie baseras på samtal bland 31 av dessa elever. Kvalitativ innehållsanalys av de inspelade gruppsamtalen visar på dilemman i form av motstridiga föreställningar och erfarenheter. Dessa frekvent talängsliga elever underströk vikten av rikligt med engelsk input och att eleverna engagerar sig och talar målspråket. Samtidigt uttryckte de att muntliga instruktioner och påbjudna talinviter på engelska ibland var obegripliga och gjorde dem osäkra. Med hänsyn till risken att skämma ut sig avstod de från att räcka upp handen för att ställa frågor, be om förtydliganden eller bidra till interaktion. Elevernas skildringar av sina emotionella erfarenheter och beteenden överensstämde därmed inte med deras föreställningar om hur språkinlärning bör gå till, vilket hämmade deras upplevda agens. Resultaten illustrerar det nära sambandet mellan föreställningar, emotionella upplevelser och agens. Implikationer för tidig språkundervisning rör målspråksanvändning och att erbjuda gott om tid och trygga situationer då elever kan öva sina muntliga färdigheter under omständigheter de upplever som trygga.

Nøkkelord: talängslan, engelska på lågstadiet, engelska på mellanstadiet, agens, målspråksanvändning, tidig språkundervisning

\section{Introduction}

Contrary to the widespread belief about the advantages of an early start of foreign language instruction, research studies have not been able to conclude any longterm benefits of lowering the starting age (Baumert et al., 2020; Pfenninger \& Singleton, 2016). The reason that such gains have not been found may have to do less with age factors per se, and more with environmental conditions and the lack of age-appropriate pedagogy (Garton \& Copland, 2019). The major benefit of English instruction in primary school may in fact not be linguistic in nature but related to long-term gains of fostering positive attitudes towards the subject and confidence in one's ability to interact in the new language (Copland \& Ni, 2019; Singleton \& Pfenninger, 2019).

At the same time, with regard to young language learners (YLLs), who have previously been regarded a rather homogeneous group, there is increasing recognition of the variety of social, psychological and personal aspects involved in teaching primary school learners (Nikolov \& Mihaljević Djigunović, 2019). A faulty assumption has been that they all take part in English lessons with ease, eagerness and confidence (Mihaljević Djigunović, 2012; Muñoz, 2017). In fact, studies in various contexts have revealed the prevalence of foreign language anxiety (FLA) also among YLLs (Liu \& Chen, 2013; Mihaljević Djigunović, 2009; Nilsson, 2019). FLA refers to "the worry and negative emotion aroused when learning and using a second language and is especially relevant in a classroom where self-expression takes place” (Gregersen \& MacIntyre, 2014, p. 3 ). The concept thus involves emotions such as embarrassment, frustration, apprehension and self-doubt (Gkonou, 2015). Furthermore, during the last 
decade, scholars within the field of language education have increasingly acknowledged the centrality of the complex interaction between learners' emotions, beliefs and their self-perceived agency (Gkonou, 2015; Kalaja et al., 2016), referred to by Mercer (2012) as their sense of agency (SoA). Researchers speak of an affective turn in SLA that may help explain the great individual variety within the same classroom that cognitive and sociocultural perspectives have yet failed to account for (Kalaja et al., 2018), and that calls attention to the powerful influence of emotional responses to instruction.

Fostering a SoA is an important goal of primary education and crucial for the well-being of young learners (Kumpulainen et al., 2014). Furthermore, early language instruction needs to counteract emergent FLA (Nikolov \& Mihaljević Djigunović, 2019). Yet, studies investigating the interaction between FLA and a SoA remain scarce, although both have a fundamental impact on learning and performance in a foreign language (Gkonou, 2015; MacIntyre, 2017). Furthermore, in order to inform the development and promotion of teaching methods suited for YLLs, and that foster their communicative competence and nurture a SoA, it is necessary to extend our knowledge of how YLLs themselves perceive foreign language instruction and classroom interaction.

In the case of adults, situations where learners perceive that their actual behavior does not match their own beliefs and expectations about language teaching have been found to result in inner conflicts that negatively affect performance, learning and emotion (Aragão, 2011; Gkonou, 2017; Yoshida, 2013a), as learners feel frustrated and unwilling to interact. A recent case study identified similar mismatches among YLLs in a Swedish target-language-only (TL-only) classroom (Nilsson, 2020). Learners who reported frequent FLA, by means of a self-report questionnaire (Nilsson, 2019), revealed that they felt unable to act in accordance with the language learner beliefs that they shared with their peers and their teacher. Similar to the studies among adults, the findings from the case study suggested a clear connection between the mismatches and learners' SoA; these YLLs failed to live up to their own beliefs and expectations, blamed themselves and refrained from interacting.

Therefore, the aim of the current study is to further our understanding of emergent FLA and SoA in primary language education, as both constructs are understood to be central to foreign language instruction. The study thus broadens the scope beyond the former single classroom case study by exploring possible mismatches between the beliefs and classroom experiences among learners with recurrent FLA across seven Swedish primary school classrooms, and how any such mismatches relate to their SoA.

In the current context, English enjoys a high status and the proficiency of the population places Sweden high in international rankings (Education First, 2019; European Commission, 2012). English is a compulsory school subject by year 3, age 9-10, but often introduced earlier. In addition, with the widespread use of English, the access to on-line games and social media, English is an everyday 
feature in the lives of many young citizens (Sundqvist \& Sylvén, 2016). The Swedish syllabus specifies aims and core content, but teaching approaches are not regulated. Thus, similarities and differences across classrooms in the same educational context, but with varying teachers and approaches, may generate insights that carry implications for English instruction in primary school beyond the context investigated.

Guided by the purpose, the methodological choice was made to narrow in on learners with the most experience of FLA in these classrooms. The term frequently anxious learners is used to refer to these participant. (Using this term is, however, not intended to give the impression that learners should be categorized or referred to in this way in the educational discourse.) The 31 participants, aged 8-12, attended school years $2-5$. Their average score on the self-report questionnaire in the prior study indicated that common classroom situations involving listening to and understanding English (such as following what the teacher was saying, making oral mistakes, or speaking in class unprepared) often, almost always or always triggered FLA for them (for the results, see Nilsson, 2019). The present study centers on the beliefs and experiences of these YLLs. Here, the term beliefs is limited to encompass learners' thoughts and ideas about the process of foreign language teaching and learning and how this ought be approached, in other words, the ideal. Experiences refer to their perceptions of what actually takes place during English lessons, including activities and interactions, as well as social and emotional dimensions. Two questions guide the study:

- In what ways do the expressed language learner beliefs and experiences in relation to oral communication align or conflict among the frequently anxious learners in these Swedish primary classroom contexts?

- Can any identified mismatches be related to learners' SoA?

\section{Background}

Several interrelated concepts are relevant to the present study, such as SoA, learner beliefs, emotions and FLA. They are all considered to be dynamic, contextual and social, as well as individual, which in itself points to the complexity of learners' cognitive and emotional interactions. These concepts will be discussed below, followed by an overview of previous research that has bearing on the present study.

\section{SoA, beliefs and emotions}

Successful language learning depends on learner engagement and agency (van Lier, 2013). Agency has been defined as "the socioculturally mediated capacity to act” (Ahearn, 2001, p. 112). A sociocultural perspective thus situates agency in the interplay between the individual and the social, and refers to ways in which 
learners perceive and respond to their context. In order to choose, act and engage in the classroom, learners need to feel agentic. Such a SoA encompasses beliefs about oneself and language learning, and perceptions of the classroom context and climate (Mercer, 2012). These perceptions involve "the ability to assign relevance and significance to things and events" (Lantolf \& Thorne, 2006, p. 143). Similarly, Sullivan and McCarthy (2004) stress that consciousness is the most central element of agency, growing out of meaning-making in relation to social interactions and where learners negotiate different, and often conflicting, priorities that they perceive. Therefore, an increased focus on the perceptions, beliefs, emotions and lived experiences of individual learners (Aro, 2016; Kalaja et al., 2018; Sullivan \& McCarthy, 2004) is necessary to frame the development of agency. Hence, in the context of the present study, SoA refers to learners' subjective perceptions of their own action potential in their language classroom environment, with cognitive as well as emotional dimensions.

Learner beliefs constitute one of the most salient dimensions of agency (Mercer, 2012). These beliefs refer to "the conceptions, ideas, and opinions learners have about L2 learning and teaching and language itself” (Kalaja et al., 2018, p. 222). Naturally, learners' perception of and approach to learning is affected by what they value and expect from themselves, and others. Learner beliefs emerge from social discourses and personal experiences (Dufva, 2003). At the same time, learners' accumulated perception of events and interactions, that is, their language learner experience (Csizér \& Kálmán, 2019), continuously helps form and modify learner beliefs. Both beliefs and experiences are therefore personal, depending on a unique and individual perspective, but also shared as the result of reciprocal interaction between individuals within a specific context (Dufva, 2003).

Similar to beliefs, emotions affect the way in which we perceive and make sense of our context, and therefore have the potential to drive or restrict agency (White, 2018), directly impacting classroom behavior (Aragão, 2011). Negative emotions of stress and apprehension in relation to language instruction, FLA, is the most studied emotion within the field of language education (MacIntyre, 2017). FLA is impacted by learner beliefs (Kalaja \& Barcelos, 2011) and thought to result from repeated negative classroom experiences that learners come to fear and expect (Gkonou, 2017). Since FLA has direct effect on our brains and bodies and interferes with cognitive processes and performance, it exerts strong influence on language learning (MacIntyre, 2017). Furthermore, FLA may decrease learners' zone of proximal development (Mahn \& John-Steiner, 2002) and have detrimental effect on the way they perceive themselves.

In sum, cognitive and emotional aspects of learning are interconnected and reciprocal (Swain, 2013; White, 2018). Furthermore, concepts such as beliefs and SoA (as well as identity and self-concept which are not discussed in this article) appear increasingly similar: dialogical, contextual, social, both individual and collective in nature. Learners in classrooms are involved in evaluations of the 
surrounding context and conditions, using their beliefs, thoughts, emotional perceptions and volition to guide their behavior (Gao, 2013).

\section{Previous research findings related to beliefs, FLA and agency}

Studies from around the world, with adult language learners, have found mismatches in learners' beliefs and experiences that may result in frustration and avoidance behaviors (Aragão, 2011; Gkonou, 2017; Yoshida, 2013a, 2013b). For example, a study on adult learners of Japanese in Australia by Yoshida (2013a) revealed how students' fear of embarrassment may hold sway over their beliefs about the importance of oral engagement, which made them reluctant to interact. Furthermore, such social concerns had a negative influence on the way students perceived themselves (Yoshida, 2013b).

In the case of children, fostering a SoA is fundamental in primary education (Kumpulainen et al., 2014). In language instruction, positive and successful engagement in activities strengthen learners' confidence and beliefs about their own potential (Arnold, 2011). Yet, studies on beliefs and agency among YLLs are scarce. Kolb (2007) found that 8-9-year-old learners were able to formulate rather detailed beliefs about language teaching that affected their own approach to learning. Muñoz (2014) interviewed learners aged 7-12, and concluded the situated nature of their preferences and beliefs. Focusing on Finnish YLLs, Aro focused on the development of beliefs and agency in children, by investigating the experiences and linguistic expressions of agency (Aro, 2009), and concluded that agency develops when the teaching approach matches the beliefs and preference of the learners (Aro, 2016). Authoritative adults influence learners' beliefs to a large extent but with time YLLs come to rely more on their own experience (Aro, 2009).

Results from Kuchah and Pinter (2012) highlighted the paramount role of emotional and relational aspects of classroom interaction for YLLs. Studies in various educational settings have confirmed FLA also in primary school, with learners who feel nervous, anxious and embarrassed when expected to speak, and possibly make mistakes, in front of peers (Gürsoy \& Akin, 2013; Liu \& Chen, 2013; Mihaljević Djigunović, 2009; Nilsson, 2019, 2020; Waddington, 2019). Macaro and Lee (2013) found that a TL-only approach with YLLs increased the risk of FLA. Moreover, FLA that is established early on not only has negative effects in the current classroom but also damaging long-term effects on learners (Nikolov \& Mihaljević Djigunović, 2019).

As stated in the introduction, a prior case study (Nilsson, 2020) set out to explore YLL beliefs and perceptions among learners with varying degrees of FLA, aged 9-10, in a Swedish TL-only classroom. The study found three ways in which frequently anxious learners' beliefs did not match their experiences and reported behavior. The first mismatch related to TL input. Despite the learners' expressed support for the TL-only approach, it confronted learners with incomprehensible input which inhibited them from responding to prompts, asking 
questions and volunteering answers. The second mismatch concerned the role of the learner. While the YLLs stressed the importance of daring to speak in class, they admitted that they themselves did not dare to do so, for fear of making mistakes in front of their peers. The third mismatch referred to work mode. Learners with recurrent FLA preferred whole-class instruction where they received guidance, scaffolding and support. Ironically, this work mode inhibited them from participating and asking questions. Yet, individual work made them fear falling behind and not managing tasks. Regardless of these mismatches, learners with frequent FLA did not criticize the teacher or question her approach. Instead, they concluded that they themselves lacked proficiency and acted in a cowardly manner. The findings suggested a conceptual model where SoA is found in the intersection between learner beliefs and emotions (Figure 1; Nilsson, 2020, p. 273).

Figure 1: Sense of agency as an overlap between learner beliefs and emotions.

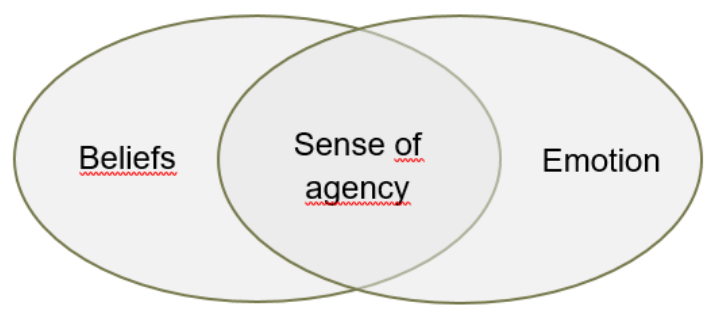

Learner beliefs in accordance with emotions, both influenced by current and previous experiences in the classroom, help empower learners to act in agreement with their own expectations. In other words, an agreement between the perceived ideal and what is perceived as real, increases the intersection and strengthens the SoA. Conversely, when language learner beliefs and emotions conflict, the SoA is weakened since learners feel inhibited and less capable to act in alignment with their beliefs. Considering the limited scope of the case study and the specific classroom, with the TL-only approach and the high prevalence of FLA, the relevance of the findings for other contexts is, however, uncertain. Hence, the present study aims to broaden the scope and our contextual understanding of FLA in YLLs and the development of a SoA in primary school, by exploring the concepts across classrooms to generate findings that may be transferable to other settings.

\section{Methodology}

\section{Data collection}

Qualitative data was collected by having YLLs sit in groups of 3 (or 4) in their classrooms to discuss questions related to language teaching and learning. Prior to this activity, lesson observations were conducted in the classrooms, for the purpose of ensuring that the discussion topics would be relevant to learners. 
Furthermore, later on these visits served as background in the analysis and also to contextualize the findings. (However, the observations are not considered to be part of data collection and are not themselves analyzed.)

In their groups, learners took turns to draw questions out of a small box to read aloud and discuss. A small hourglass was used to encourage learners to spend at least three minutes on each question and elaborate as much as possible. The open questions targeted learner beliefs about language teaching and learning, addressing issues such as TL use, classroom activities and the importance of guessing (see Appendix 1). The questions were the same as those used in the previous case study (Nilsson, 2020). All discussions were conducted simultaneously in each classroom, within the same lesson, and audio recorded. The respective teachers were not present during the activity.

In each classroom, groups were arranged so that learners shared similar levels of FLA. According to the teachers, the groupings did not appear to be related to learners' language proficiency, thus suggesting no obvious relation between FLA and proficiency in English. However, neither teachers nor learners were aware of the rationale behind the group constellations, and the teachers were confident that the grouping would not be conspicuous to learners. On a few occasions, adjustments were made due to absent learners or because teachers thought it would benefit interaction. Nevertheless, the data analyzed in the present study was generated in groups with a mean level indicating frequent experiences of FLA.

Several considerations motivated this design. Acknowledging the dialogic nature of learner beliefs, the interaction with peers, and without an adult moderator, made it possible for learners to tentatively formulate thoughts, elaborate on and spark each other's memories and negotiate meaning collectively. This group interaction was thus considered a benefit, constituting a "cognitive workspace" (Dufva, 2003, p. 53), rather than a negative influence. Moreover, it allowed YLLs favorable and safe conditions to share their thoughts and eliminated the problem of any power imbalance between learners and an unfamiliar adult researcher. The design encouraged them to interact with their peers in an activity that resembled regular classroom activities. To further empower learners to engage in the discussion, they were addressed as important and experienced informants with regards to being a YLL of English and encouraged to share their perspectives. Learners were also informed that the purpose was not necessarily to agree and that there were no right or wrong answers. Lastly, the design made it possible to collect data from all learners in each classroom on one single occasion.

The whole process was conducted in Swedish. Some groups addressed all the questions while others did not have time to. Discussions ranged from 15 to 28 minutes.

\section{Participants}

The data collection was conducted in seven classrooms, with 20-27 learners in each group, taught by six teachers, in five schools in urban and suburban areas in 
Sweden. Learners had received English instruction from year 2, at the latest. All the 161 YLLs in these classrooms took part in the activity designed for data collection. However, the present study is based on ten group discussions among learners with recurrent FLA (see Table 1). Hence, the study involves 31 learners aged $8-12$ in years $2-5$. The participants in question were not a homogeneous group apart from the fact that their total score in a previous questionnaire study (Nilsson, 2019) indicated that they frequently felt anxious during English lessons. For most of them (3/4), English made them more nervous than other school subjects. Their questionnaire response profiles differed greatly, as did their levels of language proficiency, according to their teachers.

Table 1: Overview of classroom contexts and participating learners

\begin{tabular}{|c|c|c|c|c|c|c|c|c|}
\hline \multirow[t]{2}{*}{ Aspect } & \multicolumn{7}{|c|}{ Classrooms } & \multirow[t]{2}{*}{ Summary } \\
\hline & $\mathrm{A}$ & B & $\mathrm{C}$ & $\mathrm{D}$ & $\mathrm{E}$ & $\mathrm{F}$ & G & \\
\hline School year & 2 & 3 & 4 & 4 & 5 & 5 & 5 & $\begin{array}{c}2-5 \\
\text { (age 8-12) }\end{array}$ \\
\hline $\begin{array}{l}\text { Number of } \\
\text { participants }\end{array}$ & 3 & 4 & 3 & 3 & 6 & 6 & 6 & 31 \\
\hline $\begin{array}{l}\text { Teacher's } \\
\text { language } \\
\text { use }^{\mathrm{a}}\end{array}$ & $\begin{array}{l}\text { Mostly } \\
\text { L1 }\end{array}$ & $\begin{array}{l}\mathrm{L} 1 / \mathrm{T} \\
\mathrm{L}\end{array}$ & $\mathrm{L} 1 / \mathrm{TL}$ & $\begin{array}{l}\text { Mostly } \\
\text { TL }\end{array}$ & \multicolumn{2}{|l|}{ TL-only ${ }^{\mathrm{b}}$} & $\begin{array}{l}\text { Mostly } \\
\text { TL }\end{array}$ & \\
\hline $\begin{array}{l}\text { Codes of } \\
\text { groups and } \\
\text { learners }^{c}\end{array}$ & $\begin{array}{l}\text { A: } \\
\text { P1-3 }\end{array}$ & $\begin{array}{l}\text { B: } \\
\text { P4-7 }\end{array}$ & $\begin{array}{l}\text { C: } \\
\text { P8-10 }\end{array}$ & $\begin{array}{l}\text { D: } \\
\text { P11- } \\
13\end{array}$ & $\begin{array}{l}\text { E1: } \\
\text { P14-16 } \\
\text { E2: } \\
\text { P17-19 }\end{array}$ & $\begin{array}{l}\text { F1: } \\
\text { P20-22 } \\
\text { F2: } \\
\text { P23-25 }\end{array}$ & $\begin{array}{l}\text { G1: } \\
\text { P26-28 } \\
\text { G2: } \\
\text { P29-31 }\end{array}$ & 10 groups \\
\hline
\end{tabular}

${ }^{\mathrm{a}} \mathrm{TL}=$ target language (English), L1 = first language (Swedish)

${ }^{\mathrm{b}}$ Classrooms $\mathrm{E}$ and $\mathrm{F}$ were taught by the same teacher.

${ }^{\mathrm{c}} \mathrm{P}=$ participant

The participants shared macro-level conditions as they studied English within the same national setting and curriculum, and lived in areas with similar and stable socio-economic status. At a micro-level, all learners worked in well-functioning classrooms, with teachers who were experienced and qualified to teach English to YLLs. According to the teachers, very few of the participant spoke another language than Swedish at home.

\section{Classroom contexts}

Lesson observations were conducted on at least three occasions with each teacher. The observations revealed that the teachers all had individual approaches to TL use, ranging from mostly Swedish to only English, and suggested a general increase of TL use with increasing age (see Table 1). One of the teachers in year 5 used a TL-only approach with her two groups. In the rest of the classrooms, the amount of TL use varied between lessons and activities. 
As expected, learner proficiency varied. Some learners in years 4 and 5 spoke quite fluently. The number of learners who volunteered to speak varied between classrooms but also depended on the activity. Speaking English in class, with everyone else listening, was optional in most classrooms while students were sometimes called on (in classrooms B and E). Guessing was encouraged and learners' oral contributions received feedback in the form of smiles, nods or positive appraisal but were not corrected. Sometimes the teacher would offer a recast.

The frequency of teacher-led activities decreased with students' age. Pair or group work was observed in all classrooms on all but a few occasions, and ranged from reading aloud in pairs or playing a game using certain phrases to less structured tasks such as role play or discussing favorite movies. Some teachers reminded learners to speak English, while others addressed learners in English without commenting on their language use. None of the teachers in the study ignored questions or utterances made in Swedish. The teachers seemed attentive to the needs of linguistic or emotional support of individual learners.

The atmosphere in the classrooms was perceived as warm, calm and supportive by the visiting researcher. The lessons were structured and well organized. According to the criteria suggested by Nikolov and Mihaljević Djigunović (2019), language instruction in the present classrooms appeared to fostered self-confidence, language awareness and strategy use, and could thus be considered highly qualitative, judging by the observations and the recorded group discussions.

\section{Analysis}

The data material, consisting of 3.5 hours of recordings, was transcribed in Swedish and analyzed according to the procedure of qualitative content analysis outlined by Graneheim and Lundman (2004). This analytic model considers both the descriptive, manifest content in the data and the interpretative, latent content. In other words, the analysis aimed to stay close to the actual utterances and voices of the learners while also examining underlying and recurring themes. Since each utterance was considered the product of the group interaction in this specific context, each discussion formed a unit of analysis and the contributions made were interpreted within the context of the whole discussion. Content related to language learner beliefs and classroom experiences relevant for the study, was identified, condensed and coded.

In order to identify conflicting beliefs and experiences, codes were sorted under these two major categories. This distinction may seem quite straightforward; utterances such as: 'The most important thing to learn is how to speak English' represents a belief whereas 'I think our teacher speaks too much English' or 'sometimes you just guess' represent experiences or evaluations of classroom realities. However, due to the entangled nature of beliefs and experiences, clear-cut abstractions of utterances related to human experiences are 
often not possible (Graneheim \& Lundman, 2004). For instance, comments such as 'you learn English best when you speak' or 'you learn from mistakes you make' may be either a belief or an actual experience, but are probably both - a belief concluded from personal experience, or a belief that guides the interpretation of reality. Therefore, close attention was paid to the context of the utterance, to determine whether it referred more closely to their actual experiences or their perception of what ought to take place. In other cases, a code was sorted as both an experience and a belief, it this was thought to be the case. However, such overlapping codes are not thought to compromise the analysis focusing on mismatches. Subcategories to beliefs were related to goals, language learning, lesson content and roles, whereas attitudes, self-image and one's own lesson learning process made up subcategories to experiences. Once all codes were categorized, each subcategory was examined to identify similarities and differences within and between classrooms. Then, the two major categories were compared in the same way to identify possible mismatches between beliefs and experiences, and also consider explicit or implicit relations between such mismatches and learners' SoA.

\section{Findings}

The group discussions reflected a range of beliefs, attitudes, experiences and selfassessments in relation to English instruction. Three mismatches were identified between the expressed beliefs and experiences of these YLLs, who were prone to feeling anxious in the language classroom, revolving around TL input, oral production and work mode. These mismatches, will be presented and related to learners' SoA in the following three sections, drawing on examples from the group discussions, translated into English. Learners and groups are coded according to labels in Table 1, and followed by a number indicating school year. (The superscript letters correspond to Swedish translations in Appendix 2.)

\section{Beliefs and experiences related to listening to and understanding English}

There was consensus among the students in all age groups and classrooms about the importance of having the teacher speak English, even though learners might not understand everything. That way, they claimed, learners get used to listening to the TL and practice their listening skills. Moreover, they are confronted with new vocabulary and pronunciation, and develop strategies such as guessing competence. Learners agreed that understanding every single word is not necessary, and that they are often able to draw conclusions: because of some words I know in the sentence, I can understand what she said, more or less (P18:5) ${ }^{\mathrm{a}}$. Recognizing the value of English input was more common among the older learners, in classrooms with extensive TL use. 
At the same time, learners also brought up negative aspects of dealing with incomprehensible input, as demonstrated by the following excerpt among the youngest participants $(\mathrm{A}: 2)^{\mathrm{b}}$ :

P3 it gets a bit odd if you don't understand what she's saying. Maybe she's telling us what to do and then I don't understand. It gets a bit odd.

P2 What were you going to say, P1?

P3 I don't like it when she speaks, like, English. It's like...

P1 Like, it's easier, if she says it in both Swedish...

P3 and English.

P2 I think it's good to know a bit without having translations. But I think it's good that she explains. But some words can be good to just hear. It's a bit of both. It depends.

Similarly, most discussions illustrated how listening to a lot of English is cognitively taxing, causing learners to lose their concentration, but also emotionally. This tension between emotional experiences and articulated beliefs is reflected in the following interaction (F2:5) ${ }^{\mathrm{c}}$ :

P24 sometimes it like really disturbs me when, when like the teacher says something, and I don't get it, and it's like...

P25 I think it's hard, and then it's such a relief when she says something in Swedish. It's like... I can understand you!

P24 I like tense up the whole time and just...

[...]

P23 I think it's a bit difficult, but I think it's...

P24 But sometimes, $S$ [the teacher] doesn't want to tell us in Swedish what she just said.

P23 Well, I guess it's instructive but hard.

P25 It's irritating.

P24 I suppose you get better grades in the end.

P23 It's hard, and it's a bit...

P24 Quite honestly I find it pretty irritating when the teacher says something you don't understand and then you don't like find out the answer, you just hmm...

P25 Like, I think it's hard, and you get like, oh ok, I don't understand anything but like what do I do now, but... I suppose it's good anyway.

P23 Yes.

The learners thus reasoned that TL input is challenging, but necessary and beneficial in the long run. Their discussions on the benefits and drawbacks of abundant TL use reveal that appropriate levels of TL input are a matter of difficulty level, scaffolding and content. Learners need to understand some of the 
input in order to grasp the whole and be able to follow along, and avoid feelings of anxiety and inferiority. Some support in the first language (L1) can thus be helpful and reduce the pressure that these learners experience. One learner recommended that teachers use the L1 to 'tell you, like the topic, what they will be saying, more or less... and then you can understand' (P10:4)d. Others suggested input in English should be followed by translations into Swedish, either by the teacher or by other learners.

To differing degrees, English was both the content and the means of communication in the English classrooms, depending on the teachers' TL use. One lesson aspect that learners highlighted as especially important to them, was understanding instructions. Some worried in advance: 'I will not know what to do' (P10:4) $)^{\text {e }}$ In some groups, teachers were encouraged to ask whether learners have understood, although others pointed out that they do not usually admit when they have not $(\mathrm{F} 1: 5)^{\mathrm{f}}$ :

P22 Because S [the teacher] asks us sometimes... does everyone understand? And then you don't dare say... and like nobody answers, maybe someone just says yes, and she like "oh good, then let's move on..."

The same group agreed that the teacher cannot get upset or blame learners for not having completed activities if they have not understood them. Learners relied on visual support, looking in their workbooks 'you can tell from the pages' (P14:5) ${ }^{\mathrm{g}}$ or tried to grasp from what they see their classmates doing. In classrooms where learners were encouraged or expected to speak English, some found it challenging to ask for clarifications, either because doing so in English was difficult or because it felt uncomfortable to admit not understanding. Dealing with incomprehensible input thus presented a hurdle in itself.

Summarizing learners' reflections on oral English input, the first mismatch emerges. These frequently anxious learners valued extensive TL input, in order to learn and get used to English. They were also aware of strategies they can use, such as making inferences and use visual clues. Such awareness may boost a SoA. However, they expressed that they were sometimes unable to follow the content or what was going on in the classroom. Having the teacher communicate through English was thus believed to facilitate learning but was also perceived as a hindrance to learning and engagement. Incomprehensible input had cognitive and also emotional consequences. Needless to say, failing to grasp instructions, and predicting that this will happen, will negatively impact learners' SoA, in other words, their perceived ability to act and respond. Although such situations were frustrating, learners' accounts suggest that they did not enact their agency by voicing questions in whole class. Among these learners, many were in favor of some L1 support, offered by either their teacher, or their peers. 


\section{Beliefs and experiences related to speaking English}

The YLLs in year 2 said that they learn by saying things after the teacher. To them, it was completely natural that they did not yet know a lot, and to make mistakes: 'I'm working on it, I'm a child, I go to school!' $(\mathrm{P} 3: 2)^{\mathrm{h}}$. Learners in the older age groups underscored the idea that you learn from mistakes and argued that it is important for learners to try to speak English; '...even if you say it a bit wrong, you should still try... because otherwise you don't get anywhere...you should always try, even if you say it wrong, cause then you learn from your mistakes' (P26:5) ${ }^{\mathrm{i}}$. Learners therefore need to engage and dare to try, which they were encouraged to do by their teachers. At the same time, learners found this easier said than done, as illustrated in the following extract $(\mathrm{C}: 4)^{\mathrm{j}}$ :

P10 But many think it's like embarrassing to say things wrong.

P8 Yes, but some find it embarrassing, cause it is rather embarrassing.

[...]

P10 Now, I'm thinking that like it doesn't matter... a great... it's not like the end of the world when I make a mistake, cause like then you help...

P8 But like, I think... it's not a huge deal to make a mistake, but like it is embarrassing, everyone thinks it's embarrassing to make mistakes.

P10 And you're afraid that someone will laugh, but like nobody does.

P8 Exactly, yes, it is, nobody does but you do worry.

Other discussions mirrored similar lines of reasoning $(\mathrm{G} 2: 5)^{\mathrm{k}}$ :

P30 Well yeah, I think it's good that you dare to guess, because you're trying, at least, cause if you don't try, and... then you're not doing anything, you don't learn anything, so daring to guess is good sometimes, if you don't know... cause, it might be correct.

$[\ldots]$

P30 I think the most important thing when you speak English... is probably... that you say things right, cause it feels a bit... bad if you say it wrong, even though others understand, you want to manage, and say the right things.

P31 Mm... I think it's ok, to make mistakes... considering that it's a whole new language you're trying to learn, but you'd rather, say things correctly.

$[\ldots]$

P31 Of course it's important, that you... that you try.

P29 Yes, that you like try and like still, even though you're not saying it right, it's like... it's like better to try than not saying anything, even though it's wrong.

In other words, while learners rationalized and agreed on the importance of engaging orally, they found this hard to do, and used words such 'odd, scary, embarrassing, cringe, nervous, bad' in relation to speaking. One learner said that 
being addressed in English by the teacher had a negative effect on her memory and she found herself forgetting the most common words. Another learner described how she was afraid to accidentally say something disgusting or bad $(\mathrm{P} 22: 5)^{1}$. Learners therefore needed to mobilize positive attitudes and selfconfidence, 'not pushing yourself down' $(\mathrm{P} 20: 5)^{\mathrm{m}}$ and suppress feelings of inferiority, or that 'it's no use' $(\mathrm{P} 22: 5)^{\mathrm{n}}$. From a discussion where learners had just underscored the importance of believing in oneself, the following excerpts serve to highlight these conflicting situations (E2:5) :

P17 If it's like difficult and you want to say a word but you don't dare in front of the class, then...

P18 Maybe you know it, but you're afraid of saying it wrong.

[...]

P18 Ehm... I think like this, cause if I make a mistake... when I'm speaking English, to me it feels quite embarrassing, it feels as though...

P19 Yeah.

P18 ... the whole class will laugh at me, but actually... often it's like when someone says something then maybe you laugh a little bit but then it's over. But when it's you, it stays with you a long time.

Making mistakes in front of the class thus reduced self-confidence. An inability to participate orally was, in many cases, related to incomprehensible input and could spark negative feelings in relation to the teacher. One learner voiced an emotionally loaded account of not being able respond: 'it feels so hard, when she likes asks questions and she expects and wants everyone to raise their hands and answer, but if you don't know it, it like feels as though you have let her down' $(\mathrm{P} 5: 3)^{\mathrm{p}}$. By contrast, others expressed how saying things correctly felt good, resulting in positive feedback from the teacher.

And so, in sum, these frequently anxious learners had rational discussions about mistakes being normal, unavoidable and even beneficial to learning. The groups discussed very similar principles that ought to guide learners' actions, where the role of the learner is to communicate, try and dare to speak. However, a second mismatch emerges, as learners pointed out that they themselves did not feel able to comply with this ideal. They refrained from speaking as they feared embarrassment and derision, although most spoke of this as a false fear. In this conflicting situation, learners' SoA was hampered; not only did the FLA impede their classroom performance, but they also failed to live up to their own ideals, which had a negative effect on the way they perceived themselves. According to their beliefs, learning requires engagement. Hence, they concluded that they were not doing what it takes. In order to sustain their SoA they reiterated the need to strive to assert themselves and maintain motivation. 


\section{Beliefs and experiences related to classroom organization}

To different degrees YLLs in all groups brought up the role of the teacher. Apart from providing them with TL input, the role of the teacher is to explain, show, model language use and activities so that learners can hear, see and follow along. Some learners stressed the importance of enough time to practice. Several groups brought up the benefits of group work (B:3) ${ }^{\mathrm{q}}$ :

P6 I think it's good if you work together, then maybe somebody knows some of it and someone else knows something, and then maybe you know all of it... together... your turn [P7].

P7 I think it's best when you work... in pairs, or in groups, cause then you can, if one person makes a mistake the other one can tell you, or, yes... both learn, both learn from each other.

While collaborating in groups, learners can support and help each other, but they also recognized that it feels safer, reduces stress and makes it easier for learners to concentrate and have time to think. One group (F1:5) elaborated on and advocated a scenario where they get to practice oral activities with a small group of friends and then, possibly, allow for more peers to listen to them speak, until eventually, they might feel confident enough to speak to the whole group. A few groups, however, also pointed to possible risks of pair work. A supportive partner may avoid correcting you and mislead you to overestimate your own performance (D:3). From a less supportive partner you may instead receive negative comments: 'and you never know what they may say, maybe they say you're bad or something' $(\mathrm{P} 25: 5)^{\mathrm{r}}$.

Individual work was described in terms of stress and embarrassment of asking for help and admitting that you do not understand. As several learners may need the teacher's support there is also the risk of not receiving help and fear of lagging behind (D:3)s:

P11 I can get sad when I don't get help.

P13 Me too.

P12 Yes, that can feel bad.

P11 Then I can panic, like... hello, can somebody help me, for real, time's up, like that.

P13 I know.

The third mismatch thus involves a dilemma related to work mode. On the one hand, the learners with frequent FLA preferred and needed the support that the whole-class setting offers, although they feel unable to voice queries and engage orally. On the other hand, working individually decreased support and increased the risk of falling behind. Many were in favor of pair work, although some pointed out that the risk of negative remarks increased, as the teacher did not hear 
everything that was said. Safe and supportive learning conditions were thus recurrent themes. To accommodate these needs, many affordances and social aspects must be considered in order to nurture YLLs' perceptions of agency in the language classroom.

\section{Discussion}

Aiming to explore YLL perspectives and SoA in primary classrooms, the present study set out to investigate and compare beliefs and experiences among frequently anxious learners in seven classrooms, in years $2-5$.

In response to the first research question, the group discussions revealed conflicting beliefs and experiences among these frequently anxious learners in the present context. These YLLs expressed beliefs about the importance of having the teacher speak a lot of English. Yet, incomprehensible input hindered them from responding and acting on the teacher's prompts and instructions. Furthermore, they stressed the importance of speaking and interacting in English, and overcoming fear of making mistakes although they themselves admitted not managing to do so in the classroom context. The group discussions reflected a strong reliance on teacher-led instruction in whole-class organization, although it inhibited learners from volunteering to speak, asking for clarifications or voicing questions. During individual work, on the other hand, learners lacked support and feared falling behind. In sum, learners with recurrent FLA seemed to agree to a large extent with the approach of their teachers and they expressed beliefs very much in line with the educational context and steering documents. Yet, their beliefs did not align with their own experiences. Their descriptions of their own behavior suggest that FLA exerts a more powerful influence on learners' actions than their beliefs, when these are not compatible.

The recurrent patterns confirm the same mismatches across the classrooms investigated, echoing those of the previous case study in a single classroom (Nilsson, 2020). The current study thus broadens the scope and the significance of the findings and indicates that mismatches identified among adult learners in various parts of the world (Aragão, 2011; Gkonou, 2017, Yoshida, 2013a) are found among Swedish YLLs as well, and may therefore be relevant to consider in other primary school settings. Although the learners with frequent FLA made reference to their respective classroom practices, they shared and discussed very similar experiences and reflections, in support of Dufva (2003), who suggested that learner beliefs and experiences may not only be both individual and shared within a specific group, but also generic to language learning.

A noteworthy conclusion to be drawn from these learner accounts is the role of TL use, which relates to all the three mismatches. The number of YLLs with recurrent FLA was higher in monolingual classrooms. (It is of course important to remember that most learners in all of the classrooms involved, did not 
experience frequent FLA. Still, for the YLLs who did, and who are part of the present study, the use of the TL was central to the mismatches identified). Regardless of the language approach of their respective teachers, there were compelling similarities in the group discussions across classrooms. Extensive or exclusive TL use on part of the teacher arguably has significant impact on the amount of comprehensible input for learners. Consequently, it also affects learners' capacity to respond appropriately and voice questions. Furthermore, it has implications for their ability to benefit from scaffolding and instructions for exercises or activities. These frequently anxious learners may in fact, implicitly have been discussing problems related to TL input and scaffolding outside their zone of proximal development. At the same time, teaching heterogeneous classrooms at an age where peers become increasingly important (Nikolov \& Mihaljević Djigunović, 2019) is not an easy task. Scaffolding, adapting to and assessing understanding in groups where some learners take part, ask questions and demand attention while others are quiet and do not admit to not understanding, is demanding. Studies that give voice to the perspectives of YLLs who are reluctant to engage during English lessons is one way of addressing these challenges involved in early English instruction and gain deeper understanding of the role and nature of FLA and SoA among YLLs.

In response to the second research question, the identified mismatches are clearly related to learners' SoA. These YLLs perceived themselves as less agentic, not only due to their FLA, but also because their actions did not align with their own beliefs about constructive behavior. Emotions at odds with beliefs thus appeared to weaken learners' SoA. As highlighted by Sullivan and McCarthy (2004), negotiation and meaning-making are central to agency. While Aro (2016) found that YLLs' SoA was dependent on the match between the teacher's approach and the preferences of the learners, the present study suggests that such alignment is not enough. In fact, the normative classroom discourse that stresses communication over accuracy and aims to create a safe and allowing classroom atmosphere, may add to the problem; for frequently anxious learners, subscribing to such beliefs but concluding their failure to act accordingly, negatively impacts the way they perceive themselves and their action potential. Not only do they need to cope with FLA, which is both cognitively and emotionally taxing, but they also engage in supportive self-talk to maintain motivation.

Findings underscore the central role of emotion and the situated nature of a SoA in the primary English classroom. The discussion prompts, that focused on YLLs' learner beliefs and their own approach and behavior, generated discussions that foregrounded emotional experiences and the social context. The study thus offers further support for the model (see Figure 1), where SoA is conceptualized as an overlap between learners' beliefs and emotions. If learners' emotional experiences were better aligned with their beliefs, their SoA would probably be strengthened, opening up for more experiences of success and engagement, in a positive cycle. Conversely, the opposite situation is negative because once the 
pattern of non-engagement is established it leads learners to confirm their feelings of incompetence and to develop negative expectations of their own ability to understand and perform, weakening their SoA. Consequently, learners miss out on opportunities for positive feedback and experiences of successful communication, which are key to the development of agency in YLL (Aro, 2016).

\section{Implications}

With reference to the suggested model (Figure 1), the challenge facing teachers is how to push the circles together, to increase the overlap and create opportunities for learners to act in accordance with their beliefs and thereby nurture learners' self-perceived agency. TL use was central to the mismatches accounted for. On a positive note, this is a dimension of language instruction over which teachers have direct control. The possible benefits of L1 support should be considered, as suggested by several researchers (e.g., Copland \& Ni, 2019; Littlewood \& Yu, 2011). Clearly, TL input is crucial in foreign language learning (e.g., Gass, 1997). However, to counteract FLA, the present findings point to the importance for YLLs of grasping instructions. As Littlewood and Yu (2011) point out, these are often conveyed in more complex language than activities themselves contain. Early language education is rather teacher-centered by default, considering YLL's limited proficiency and concentration span, and the oral focus. A monolingual approach where the teacher is the only one who masters the means of communication may arguably raise the threshold for learners as they consider responding and volunteering to speak.

Although the study focuses on learners with frequent language anxiety the findings should not be interpreted to suggest that teachers should categorize their learners this way. Instead, the study hopes to inspire teachers to consider FLA as a contextual phenomenon related to teaching approaches and classroom atmosphere (Nilsson, 2019). Many of the YLLs in this study called for more opportunities to practice speaking English with supportive partners in pairs or small groups. To cater to the needs of more hesitant learners, instruction thus needs to offer scaffolding and input in full class while offering safe conditions for output with limited social exposure. Apart from reducing the face-threatening speech in front of the whole group, such activities increase talk-time and the experience of oral communication for all learners.

These primary learners were eager to share their thoughts and experiences and found it interesting to discuss the topics with their peers. As suggested by Aragão (2011) and Gkonou (2017), addressing and encouraging groups to share and reflect on language learner beliefs but also their experiences, may have positive effects, also for YLLs.

The classrooms in this study were rather similar and are not representative of the Swedish context as a whole. Instead, variation in variables such as socioeconomic status and linguistic background, which are beyond the control of individual teachers, were reduced. The findings thus illustrate the perceptions of 
learners with recurrent FLA in classrooms with qualified teachers, wellfunctioning classrooms and no grades or high-stakes exams. As for methodology, an important limitation of the data collection design is the fact that it was not possible to ask learners for further elaborations or clarifications that would sometimes have facilitated analysis and interpretation. The social dimensions of the co-constructed meaning-making among learners may have accentuated agreement and led learners to withhold diverging opinions or experiences. Discussions with an unfamiliar researcher is not, however, likely to have resolved the risk of such drawbacks. Instead, the design sought to empower YLLs to engage in dialogic exploration and negotiation with their peers, and allowed for as many as 31 participants to voice and share their personal experiences of classroom instruction. Only the author, who had conducted the lesson observations, was involved in data analysis, which is another related limitation.

\section{Conclusion}

The study identifies mismatches among frequently anxious primary learners of English, as their beliefs about the processes involved in language teaching and learning conflict with their actual experiences. Furthermore, findings suggest that learners' SoA is weakened in situations where they feel unable to meet their own expectations. The findings shed light on crucial aspects of early language instruction that concern TL use, the need to scaffold and support learners' perceptions of their own capacity and willingness to interact, and to organize activities that reduce social exposure. The results imply that even in wellfunctioning, supportive classrooms a considerable amount of YLLs' experience mismatches that reduce the SoA that primary education should aim for. More research that builds on the perspectives of young learners, in other educational and sociocultural contexts would be valuable and help further our understanding of YLLs and the ways in which they engage with and respond to language instruction. Such studies may also advance our understanding of the extent to which FLA and SoA can be related to teaching approaches in primary school, and aspects that may be more generic in early language instruction. 


\section{About the author}

Maria Nilsson is a postdoctoral researcher at the English Department at Uppsala University in Sweden. She has many years' experience of teaching languages in compulsory school, and in university courses for pre-service and in-service primary teachers. Her research interests involve English language teaching for young learners and primary school teacher education.

Institutional affiliation: Uppsala Universitet, Engelska Institutionen, Box 527, 75120 Uppsala.

E-mail: maria.nilsson@engelska.uu.se

\section{References}

Ahearn, L. M. (2001). Language and agency. Annual Review of Anthropology, 30(1), 109137.

Aragão, R. (2011). Beliefs and emotions in foreign language learning. System, 39(3), 302313. https://doi.org/10.1016/j.system.2011.07.003

Arnold, J. (2011). Attention to affect in language learning. Anglistik. International Journal of English Studies, 22(1), 11-22.

Aro, M. (2009). Speakers and doers: Polyphony and agency in children's beliefs about language learning [Doctoral dissertation, University of Jyväskylä].

Aro, M. (2016). In action and inaction: English learners authoring their agency. In P. Kalaja, A. M. F. Barcelos, M. Aro, \& M. Ruohotie-Lyhty (Eds.), Beliefs, agency and identity in foreign language learning and teaching (pp. 48-66). Palgrave Macmillan.

Baumert, J., Fleckenstein, J., Leucht, M., Köller, O., \& Möller, J. (2020). The long-term proficiency of early, middle, and late starters learning English as a foreign language at school: A narrative review and empirical study. Language Learning, 1-45. https://doi.org/10.1111/lang.12414

Copland, F., \& Ni, M. (2019). Languages in the young learner classroom. In S. Garton \& F. Copland (Eds.), The Routledge handbook of teaching English to young learners (pp. 156171). Routledge.

Csizér, K., \& Kálmán, C. (2019). A study of retrospective and concurrent foreign language learning experiences: A comparative interview study in Hungary. Studies in Second Language Learning and Teaching, 9(1), 225-246. https://doi.org/10.14746/ssllt.2019.9.1.10

Dufva, H. (2003). Beliefs in dialogue: A Bakhtinian view. In P. Kalaja \& A. M. F. Barcelos (Eds.), Beliefs about SLA (pp. 131-151). Springer.

Education First. (2019). EF English Proficiency Index. https://www.ef.se/epi/

European Commission. (2012). First European survey on language competences: Final report.

https://crell.jrc.ec.europa.eu/sites/default/files/files/eslc/ESLC_Final\%20Report_210612.p df

Gao, X. (2013). Reflexive and reflective thinking: A crucial link between agency and autonomy. Innovation in Language Learning and Teaching, 7(3), 226-237. https://doi.org/10.1080/17501229.2013.836204 
Garton, S., \& Copland, F. (2019). Introduction. In S. Garton \& F. Copland (Eds.), The Routledge handbook of teaching English to young learners (pp. 1-10). Routledge.

Gass, S. M. (1997). Input, interaction, and the second language learner. Routledge. https://ezp.sub.su.se/login?url=http://search.ebscohost.com/login.aspx?direct=true\&db=nl ebk\&AN=564058\&site=ehost-live \&scope $=$ site

Gkonou, C. (2015). Agency, anxiety and activity: Understanding the classroom behavior of EFL learners. In P. Deters, X. Gao, E. R. Miller, \& G. Vitonova (Eds.), Theorizing and Analyzing Agency in Second Language Learning: Interdisciplinary approaches (pp. 195212). Multilingual Matters.

Gkonou, C. (2017). Towards an ecological understanding of language anxiety. In C. Gkonou, M. Daubney, \& J.-M. Dewaele (Eds.), New insights into language anxiety: Theory, research and educational implications (pp. 135-155). Multilingual Matters.

Graneheim, U. H., \& Lundman, B. (2004). Qualitative content analysis in nursing research: Concepts, procedures and measures to achieve trustworthiness. Nurse Education Today, 24(2), 105-112. https://doi.org/10.1016/j.nedt.2003.10.001

Gregersen, T., \& MacIntyre, P. D. (2014). Capitalizing on language learners' individuality: From premise to practice. Multilingual Matters.

Gürsoy, E., \& Akin, F. (2013). Is younger really better? Anxiety about learning a foreign language in Turkish children. Social Behavior and Personality, 41(5), 827-841. https://doi.org/10.2224/sbp.2013.41.5.827

Kalaja, P., \& Barcelos, A. M. F. (2011). Beliefs in second language acquisition: Learner. In C. A. Chapelle (Ed.), The encyclopedia of applied linguistics. Wiley Blackwell. https://doi.org/10.1002/9781405198431.wbeal0082

Kalaja, P., Barcelos, A. M. F., \& Aro, M. (2018). Revisiting research on L2 learner beliefs: Looking back and looking forward. In P. Garrett \& J. M. Cots (Eds.), The Routledge handbook of language awareness (pp. 222-237). Routledge.

Kalaja, P., Barcelos, A. M. F., Aro, M., \& Ruohotie-Lyhty, M. (2016). Beliefs, agency and identity in foreign language learning and teaching. Palgrave Macmillan.

Kolb, A. (2007). How languages are learnt: Primary children's language learning beliefs. International Journal of Innovation in Language Learning and Teaching, 1(2), 227-241. https://doi.org/10.2167/illt033.0

Kuchah, K., \& Pinter, A. (2012). 'Was this an interview?' Breaking the power barrier in adult-child interviews in an African context. Issues in Educational Research, 22(3), 283297.

Kumpulainen, K., Lipponen, L., Hilppö, J., \& Mikkola, A. (2014). Building on the positive in children's lives: A co-participatory study on the social construction of children's sense of agency. Early Child Development and Care, 184(2), 211-229. https://doi.org/10.1080/03004430.2013.778253

Lantolf, J. P., \& Thorne, S. L. (2006). Sociocultural theory and the genesis of second language development. Oxford University Press.

Littlewood, W., \& Yu, B. (2011). First language and target language in the foreign language classroom. Language Teaching, 44(1), 64-77.

https://doi.org/10.1017/S0261444809990310

Liu, H., \& Chen, T. (2013). Foreign language anxiety in young learners: How it relates to multiple intelligences, learner attitudes, and perceived competence. Journal of Language Teaching and Research, 4(5), 932-938. https://doi.org/doi:10.4304/jltr.4.5.932-938

Macaro, E., \& Lee, J. H. (2013). Teacher language background, codeswitching, and Englishonly instruction: Does age make a difference to learners' attitudes? TESOL Quarterly, 47(4), 717-742. https://doi.org/10.1002/tesq.74 
MacIntyre, P. D. (2017). An overview of language anxiety research and trends in its development. In C. Gkonou, M. Daubney, \& J.-M. Dewaele (Eds.), New insights into language anxiety: Theory, research and educational implications (pp. 11-30). Multilingual Matters.

Mahn, H., \& John-Steiner, V. (2002). The gift of confidence: A Vygotskian view of emotions. In G. Wells \& G. Claxton (Eds.), Learning for life in the 21st century: Sociocultural perspectives on the future of education (pp. 46-58). Blackwell Publishers.

Mercer, S. (2012). The complexity of learner agency. Apples - Journal of Applied Language Studies, 6(2), 41-59.

Mihaljević Djigunović, J. (2009). Individual differences in early language programmes. In M. Nikolov (Ed.), The age factor and early language learning. (pp. 199-225). Mouton de Gruyter.

Mihaljević Djigunović, J. (2012). Attitudes and motivation in early foreign language learning. CEPS Journal: Center for Educational Policy Studies Journal, 2(3), 55-74.

Muñoz, C. (2014). Exploring young learners' foreign language learning awareness. Language Awareness, 23(1-2), 24-40. https://doi.org/10.1080/09658416.2013.863900

Muñoz, C. (2017). Tracing trajectories of young learners: Ten years of school English learning. Annual Review of Applied Linguistics, 37, 168-184. https://doi.org/10.1017/S0267190517000095

Nikolov, M., \& Mihaljević Djigunović, J. (2019). Teaching young language learners. In X. Gao (Ed.), Second handbook of English language teaching (pp. 1-23). Springer International Publishing. https://doi.org/10.1007/978-3-319-58542-0_31-1

Nilsson, M. (2019). Foreign language anxiety: The case of young learners of English in Swedish primary classrooms. Apples - Journal of Applied Language Studies, 13(2), 1-21. https://doi.org/10.17011/apples/urn.201902191584

Nilsson, M. (2020). Beliefs and experiences in the English classroom: Perspectives of Swedish primary school learners. Studies in Second Language Learning and Teaching, 10(2), 257-281. http://dx.doi.org/10.14746/ssllt.2020.10.2.3

Pfenninger, S. E., \& Singleton, D. (2016). Affect trumps age: A person-in-context relational view of age and motivation in SLA. Second Language Research, 32(3), 311-345. https://doi.org/10.1177/0267658315624476

Singleton, D., \& Pfenninger, S. E. (2019). The age debate: A critical overview. In S. Garton \& F. Copland (Eds.), The Routledge handbook of teaching English to young learners (pp. 30-43). Routledge.

Sullivan, P., \& McCarthy, J. (2004). Toward a dialogical perspective on agency. Journal for the Theory of Social Behaviour, 34(3), 291-309. https://doi.org/10.1111/j.00218308.2004.00249.x

Sundqvist, P., \& Sylvén, L. K. (2016). Extramural English in teaching and learning. Springer.

Swain, M. (2013). The inseparability of cognition and emotion in second language learning. Language Teaching, 46(02), 195-207. https://doi.org/10.1017/S0261444811000486

van Lier, L. (2013). Control and initiative: The dynamics of agency in the language classroom. In J. Arnold \& T. Murphey (Eds.), Meaningful action: Earl Stevick's influence on language teaching (pp. 241-251). Cambridge University Press.

Waddington, J. (2019). Developing primary school students' foreign language learner selfconcept. System, 82, 39-49. https://doi.org/10.1016/j.system.2019.02.012

White, C. J. (2018). The emotional turn in applied linguistics and TESOL: Significance, challenges and prospects. In J. de D. Martínez Agudo (Ed.), Emotions in second language teaching: Theory, research and teacher education (pp. 19-34). Springer International Publishing. https://doi.org/10.1007/978-3-319-75438-3_2 
Yoshida, R. (2013a). Conflict between learners' beliefs and actions: Speaking in the classroom. Language Awareness, 22(4), 371-388.

https://doi.org/10.1080/09658416.2012.758129

Yoshida, R. (2013b). Learners' self-concept and use of the target language in foreign language classrooms. System, 41(4), 935-951.

https://doi.org/10.1016/j.system.2013.09.003 


\section{Appendix 1}

Questions used in the independent group discussions

\section{Original in Swedish:}

- Tycker du att det är bra eller dåligt att läraren pratar mycket engelska även om eleverna inte förstår allt? Förklara hur du tänker.

- Tror du att olika personer lär sig engelska på olika sätt? Berätta.

- Vad tycker du är viktigast när du pratar engelska - att det du säger är rätt, eller att andra förstår vad du menar, även om du säger lite fel?

- Tycker du att det är smart att chansa, när det är något man inte kan på engelska?

- Känner du att du lär dig mycket på att öva och repetera och göra saker flera gånger?

- Hur tror du att du bäst lär dig prata engelska? Förklara hur du tänker.

- Vad tycker du är det viktigaste att lära sig i engelska? Varför?

- Hur lär du dig engelska bäst? Berätta.

- Tror du att du kommer att bli väldigt duktig på engelska när du blir äldre?

- Lär du dig bäst när du lyssnar eller när du talar? Förklara hur du tänker.Hur känner du dig när ni jobbar med något i engelska som är nytt eller lite svårt? Berätta.

- Tror du att man lär sig mycket av att härma och säga efter andra? Förklara hur du tänker.

- Tycker du att det är naturligt att göra fel när man lär sig engelska? Berätta.

English translations:

- Do you think it's good or bad that the teacher speaks a lot of English even

- though the students may not understand everything? Explain what you think.

- Do you think different people learn English in different ways? Tell me.

- What do you think is most important when you speak English - that what you say is correct or that others understand what you mean, although you may say things a bit incorrectly?

- Do you think it's smart to guess when there is a word you don't know in English?

- In your experience, do you learn a lot by practicing and repeating and doing things several times?

- What do you think is the best way to learn how to speak English? Explain what you think.

- In your opinion, what are the most important things to learn in English? Why?

- What is the best way for you to learn English? Tell me.

- Do you think you will be quite good at English once you get older?

- Do you learn best when you listen or when you speak? Explain what you think.

- How do you feel when you are working with something that is new or a bit difficult. Tell me.

- Do you think you learn a lot by imitating and repeating after others? Explain what you think.

- Do you believe it’s natural to make mistakes when you learn English? Tell me. 


\section{Appendix 2}

Excerpts from group discussions in Swedish.

\section{Excerpt a: E2:5}

P18 Men... det finns ju såhär vissa ord som jag... liksom... inte ens förstår, men på grund av vissa ord jag kan i meningen kan jag förstå vad det är hon sa, ungefär.

P17 Ja.

P18 Så... det är liksom det är ok för mig, för att jag, jag tror att jag lär mig av det, jag vet själv inte om jag lär mig av det men jag tror det.

\section{Excerpt b: A:2}

P3 ... det blir lite konstigt om man inte förstår vad hon säger. Hon kanske berättar vad man ska göra och då fattar ju inte jag. Det blir lite konstigt.

P2 Vad tänkte du säga, L1?

P3 Jag gillar inte när hon pratar liksom engelska. Det är liksom...

P1 Alltså, det är lite lättare, om hon säger både på svenska...

P3 ... och engelska.

P2 Jag tror det är bra att kunna lite utan att få veta. Men jag tycker att det är bra att hon förklarar. Men vissa ord kan det vara bra att bara höra. Jag tror det är lite blandat. Det beror på.

\section{Excerpt c: F2:5}

P24 … ibland så blir jag såhära jättestörd på att, när, när liksom läraren säger nånting, och så fattar jag inte, och så är det liksom...

P25 Jag tycker det är jobbigt, och sen blir det jätteskönt när hon säger någonting på svenska. Jag bara... Jag kan förstå dig!

P24 Jag sitter typ på spänn hela tiden och bara...

$[\ldots]$

P23 Jag tycker det är lite jobbigt, men jag tycker att det är...

P24 Men ibland så vill inte S [the teacher] berätta på svenska vad det var hon sa.

P23 Alltså, det är väl lärorikt men jobbigt.

P25 Det är irriterande.

P24 Man får väl högre betyg i slutändan.

P23 Det är jobbigt, och det är lite...

P24 Helt ärligt tycker jag det är ganska irriterande när lärare säger något man inte fattar och så får man liksom inte reda på svaret, man bara hmm,.

P25 Asså, jag tycker det är jobbigt, och så blir man såhär, jamen ok, jag fattar ingenting men vad ska jag göra nu typ, men... det är väl bra ändå, antar jag.

P23 Ja.

Excerpt d: P10:4

att de berättar, ämnet liksom, vad de ungfär kommer att säga... och sen så fattar man

Excerpt e: P10:4:

jag kommer inte fatta vad man ska göra

Excerpt f: F1:5 
P22 För att S [läraren] frågar ju ibland såhära... 'förstår alla?' och då vågar man ju inte säga såhär... och typ ingen svarar, det är kanske nån som bara säger ja, hon bara ’jamen bra då fortsätter vi da'...

Excerpt g: P14:5

man ser ju på sidorna

Excerpt h: P3:2

Jag jobbar ju med det, jag är ju ett barn, jag går i skolan!

Excerpt i: P26:5

även om man, om man säger lite fel, så ska man ändå försöka... för annars så kommer man ju ingenstans [...]... man ska alltid försöka, även om det blir fel, för då lär man sig av sina misstag.

Excerpt j: C:4

(P8 Ja, det [att säga fel] är ju jättevanligt...

P10 Det är jättebra.

P9 Det är bara bra att göra fel, för då kan man ju lära sig.

P10 Lära sig av sitt misstag.

P8 Ja, typ.)

P10 Men, många tycker att det typ är pinsamt att säga fel.

P8 Ja, men många tycker ju att det är pinsamt, för det är ju rätt pinsamt.

$[\ldots]$

P10 Nu, så tänker jag såhär att det spelar inte så... jättestor... det är liksom hela världen att jag gör fel, för att då liksom hjälper man... liksom... och då...

P8 Men asså, jag tycker att... det är inte jättefarligt att göra fel, men asså det är pinsamt, alla tycker att det är pinsamt att göra fel.

P10 Och man är rädd att någon ska typ skratta, men det gör typ ingen.

P8 Exakt, ja, det är det, det gör ingen men man är rädd.

Excerpt k: G2:5

P30 Jo asså, jag tycker det är bra att man chansar, för man försöker, i alla fall, för om man inte försöker, och... då gör man ju ingenting, man lär sig ingenting, så det är bra att man chansar ibland, om man inte vet... eftersom, att, det kan vara rätt.

$[\ldots]$

P30 Jag tycker nog att det viktigaste när man pratar engelska... det är nog... att man säger rätt, för det känns lite... dåligt om man säger fel, även fast man förstår, man vill ju klara av, och säga rätt saker...

P31 Mm... jag tycker att det är ok, att säga fel... på tanke på att det är ett helt nytt språk man försöker lära sig, men man vill helst, säga rätt.

$[\ldots]$

P31 Det är ju förstås viktigt, att man... att man försöker.

P29 Ja, att liksom man försöker och liksom ändå, även fast man inte säger rätt så är det ju liksom... det är liksom bättre att försöka än att inte säga nånting, även fast man säger fel.

Excerpt l: P22:5

Jag är faktiskt rädd för att liksom ifall jag råkar säga nåt äckligt, nåt snuskigt eller nåt fult eller nåt. 
Excerpt m: P20:5

inte trycka ner en själv

Excerpt n: P22:5

det är ingen idé

\section{Excerpt o: E2:5}

(P17 Man ska ju tro på sig själv, man ska inte tänka vad på de andra, vad de säger.

P18 Man ska tro på sig själv.

P19 Ja, fast man kanske tycker att det är pinsamt, för att vi säger att du har sagt något felt [sic] ord, då blir det såhär kanske att man bara, hihi, liksom lite, då tycker man själv, det där var inte så skönt och så.)

$[\ldots]$

P17 Om man såhär har svårt och man vill säga nåt ord men man vågar ju inte i klassen, då...

P18Man kanske vet det, men man är rädd att man ska säga fel.

$[\ldots]$

P18 Ehm... jag tycker såhär, för att om jag säger fel... när jag pratar engelska, så tycker jag själv att det känns väldigt pinsamt, det känns som att...

P19 Ja.

P18 ... hela klassen kommer att skratta ut mig, men egentligen... så är det ofta såhär när någon säger någonting så kanske man skrattar lite men sen är det över. Men för en själv så sitter det kvar.

\section{Excerpt p: P5:3}

det känns så jobbigt, när hon liksom frågar frågor och hon tror och vill att alla ska räcka upp handen och säga det, men om man inte kan det så liksom känns det som att man har svikit henne

\section{Excerpt q: B:3}

P6 Jag tycker det är bra om man jobbar med flera, då kanske någon kan något och nån annan kanske nåt, så kan man kanske allting... allting tillsammans... din tur L7.

P7 Jag tycker att det är bäst när man jobbar... två, eller i grupp, för då kan man, om den ena gör fel så kan den andra säga åt en, eller, ja... att båda lär, att båda lär varandra.

P4 Ja, och jag tycker att... jag gillar att jobba med kompisar för om man inte kan en sak då kan man fråga den, om den kan.

Excerpt r: P2:5

Och man vet ju aldrig vad de kan säga, de kanske säger å vad dålig du är, eller nåt...

\section{Excerpt s: D:3}

P11 Jag kan bli ledsen om jag inte får hjälp.

P13 Jag med.

P12 Ja, då kan det bli lite jobbigt.

P11 Då kan jag få panik, ba... hallå, kan nån hjälpa mig, på riktigt, nu är tiden slut, liksom så.

P13 Jag vet. 